\title{
For Whom Does the Speaking Woman Speak?
}

\author{
Vyncent Elvin Eebee
}

Department of General Studies, School of Foundation Studies, Rivers State Polytechnic, Bori-Nigeria

Doi:10.5901/mjss.2014.v5n26p22

\begin{abstract}
Since the first ever International Women Conference, the plurality of female voices addressing the issue of women's inequality, marginality and empowerment has flourished. The credibility and authenticity of these voices have been questioned. Rather than helping woman, these questions have deepened the chasm between the rural woman's voice and the voice of the urban female advocate.It is the contention of this paper that the representation of the rural woman's experience as subject fails the authenticity and fidelity criteria because the rural women is invisible in the articulation of her voice by the other. When the rural woman ever participates in action, it is upon trumpeted and highly advertised invitations. The structure of the relationship between her and them is downward sloping than horizontal. This has effect on the nature and success of activism. In effect, the rural woman is yet to speak for and on behalf of herself. This paper seeks to know whose voice is telling the rural woman's story and argues that the mediation by the urban advocate appears more elitist than grassroots especially with programmes of action constructed like intellectual activism rather than participatory mass movements.
\end{abstract}

Keywords: For whom the speaking woman?

The campaign for a better deal for women in today's global society has assumed a critical crescendo that it is difficult for anyone to ignore it without causing himself a level of self-inflicted discomfort. The agitations are here and many have lent their voices to the struggle for gender equality and liberty. Significantly, while the women of the western world appear to emphasize freedom, the African/Nigerian woman is rather asking for liberty in a rather more inclusive manner. In other words, what often differentiates the western feminist activist from the Nigerian feminist activist is whether the modus operandi of the protests is centrifugal or centripetal. This has been largely influenced by indigenous cultural imperatives. Local reality on the African continent,as in other climes, calls for prudent adaptation of techniques and tactics for effective strategic results in mass mobilization. Outside this, the originary discontent among women globally is similar and the basic conditions that produce it are also closely identical. Most often, the conditions that account for the subjective conditions of women are blamed on male chauvinism or patriarchy. This has led to accusations that women have been made objects rather than subjects and that the issue of gender is more political than natural. Thus, the struggle against the thingification of the woman as a subject of humanistic enquiry has been distorted even further by intra-women dissensions and counter-offensives. The transition from theory to practice is mediated by social activism. The rise in the size and magnitude of various forms of feminist social activism has given rise to the emergence of several advocacy groups claiming to speak on behalf of women. This claim of representative capacity has however raised critical questions as to the capacity, character and dimensions of the representative voice. This is the focus of our attention in this paper within the rubric of gender activism and the politics of representation and re-presentation.

The transition from theory to pragmatics, from conference halls to physical protests and street marches in women's struggle against the political interpretation of gender has been fraught and often has ended in name-calling, frustrations and further levy of marginalization. Yet, progress has been made and is being made. The challenges facing the issue of authentic voice in women and gender studies stem from the very diversity of the generating conditions of the multiplicity of crises confronting women as subjective agents. The notion of predetermined biological sexesis currently facing a formidable challenge from social theorists who are progressively deconstructing and contesting the fixity of biology with the argument that even nature itself is alterable in terms of social reality. This has exacerbated the dismantling of most theories of the impenetrability and inalterability of the character of natural sex boundaries especially with the many successful cases of change in sex status which many in the West are currently embracing. Persons who were supposedly born male years ago are constantly procuring the services of high-tech medical science to alter their sex group from male to female just as females are doing the reverse.

Today's world now accommodates the transgendered, the multi-sexed and Anne Fausto-Sterling's"The Five Sexes" (1993) which relies heavily on epistemic privilege as grounds for justification of her arguments disputesempirically the notion of binary sex as she continues to denounce the binary division of sex and sex roles. This behaviour promotes 
the current debate as to whether creation actually made the sexes inalterable. The deconstruction of sexual rigidity has further emboldened the argument that a person is either male or female by nurture rather than by nature. Consequently, the individual's self-knowledge of a sense of sex group plays a critical role in the patterns of activism the individual chooses to pursue and the character of voice that can claim to represent it. For instance, lesbians would find it hard to be led by heterosexual activists or believe that such persons with heterosexual orientation would adequately represent their interest. This endangers the legitimacy of whatever voice that might claim to be speaking on their behalf. And the primacy of legitimacy in voice is key to advocacy in terms of both as representation and re-presentation.

I have decided to establish this background because the florilegium of gender advocates who have claimed authority to speak on behalf of womenthrows up concerns on the nature and character of voice in authentic speaking and representation. Democracy allows a plurality of voices to flourish but this flourish if not monitored or regulated by any regime of parametric or indexicalframework becomes a problem to the act of representation and the articulation of a voice. This problem reproduces itself largely in "speaking on behalf of". That is, re-presenting someone else's de se knowledge. Writers, actors, social commentators and civil society groups always do speak in such representative and representative capacity with or without the authorization of the person(s) concerned. In the process, no one determines ab initio, who has the authority to speak on behalf of another and representation and advocacy become an all-comers affair. Applied to the woman's search for voice and space, we see a dangerous trend that develops beyond the concern for altruistic mediation and which rather focalises mediation with reward either in pecuniary terms or in terms of fame and recognition. Thus, apart from contending with the subjective conditions that deprive the woman of fulfilled existence, the issue of representation and voice further aggravates the dilemma and complications of invisibility.

Whose voice is heard in any narrative at all? It should be that of the subject telling her story. However, when a voice is 'borrowed' to re-present another voice's knowledge, what happens to the prejudices and epistemic experiences of the speaker which must be subordinated to in order to represent someone else? I suppose they must continue to struggle to express themselves and by so doing would almost certainly undermine standpoint to an extent. A voice that represents (that speaks for) assumes cognitive responsibility and recreates factsbased on testimony while the represented actually acquires subjectivity through direct experience and therefore retains epistemic authority over reality (Addelson 1983; Code 1991). Since a majority of women are mostly seen and not heard, the meeting point of the representative and the represented must be negotiated in the voice. Some women are neither seen nor heard while a negligible but vocally few are both heard and seen on behalf of the other multitude. The effect of this situation remains that a vast majority of concerned victims of social inequalities and oppression are unrepresented or unheard. It is sad and frustrating that these voiceless persons do not count in national development because they remain invisible.

Within the context of gender studies and the fast expanding discourse on the authenticity of voice (both speaking and spoken for) especially within the rubrical frame of feminist activism, I foresee a further complication of the woman's dilemma by internal as well as external contentions that are at once both existential and political. Intra-women contentions arising from locationality or positionality continue to evolve in a dialectical mannerthat appears to crystallize in the progressive ascendancy of the urban feminist advocate and a correspondingimmanence and distanciation of the impoverished rural woman. She becomes the movable pieces in the puzzle that can be used not for her ends but for others' end. Thus, while urban-based advocacy procures for the representing voice prominence and related perquisites, the sites of the actual crisis are further distanced from the core contents of mobilizations and related activism. In other words, the very nature and character of the many gynaphiliac urban organizations that claim to speak on behalf of the rural female folk actually make guinea pigs of them. There are, however, positive achievements recorded in the activities of some faith-based organizations which continue to encourage women especially widows to take action themselves through a re-invigoration of their religious convictions in an almost imperceptible and noiseless manner.

The organization of workshops, talk shops, conferences, seminars and symposia in five-star hotels clearly indicate the elitist character of the urban-based voice. They are and remain the products of snob mentality and dissimulated classism. A classic case that typifies the authenticity of voice can be located in the sudden rise of women during the Ogoni revolution between 1992 and 1996. For the Ogoni whose land has been devastated by years of mindless oil exploration inequities occasioning huge environmental catastrophes, the mobilization of Ogoni women became successful because it was built upwards rather than downwards. Ogoni women had to speak for themselves or through their elected officials who were nominated from the community organizational units. Bori was the usual meeting point and at no time was any conference or symposium held outside Ogoni land. The process and the outcomes of rallies, vigils, commitments and marches became property of popular ownership. Apart from conferring credibility on the voice of the women and men, this re-enforced the integrity of participation and gave vent to quality decisions.In all these, the mass movement organisation, MOSOP engineered the process.

How did Ogoni women recover voice and achieve visibility in the Ogoni revolution and why is there today a 
paralysis in the ranks of the women? How did they appropriate this voice to tell their own story? What is the measure of their challenge, success and failure if any? Why,in the first place, did MOSOP focus on the mobilizationof rural women for the successful repossession of their farmland devastated by Shell Exploration Company? Was there any disconnect between the voice and the advocate in the course of political activism? These posers are key pointers to the possibilities achievable in voice and advocacy by and among women. Gender studies must account for the exceptionally unsuccessful models or forms of contemporary representation which appear clearly to be more academic than practical, more urban than rural and more class-defined than mass-inspired.

The success of the Movement for the Survival of the Ogoni People (MOSOP) as an activist organisation grounded in grassroots mobilization under the late writer/environmentalist Ken Saro-Wiwa is traceable to his knowledge of mass movementculture and the role of the intellectual as a leading light of the community. From the beginning of the revolution, the driver of the mass participation was located in the mould of mobilization, especially, of women as a critical mass. The military government in power then was a brutal aberration and confronting them with adversarial elements (i.e. just males) could have only resulted in more devastating fatalities. Women with green- leaves in protest then became the most potent force on the streets to confront a junta whose bloodthirsty appetite was legendary. Ken Saro-Wiwa'sevident success is therefore traced toboth his choice of vanguard and the authenticity of the voice communally surrendered to him. Thus, he became botha representative and an advocate. This added bounce to his extraordinary ability toinnovate and provide the nexus between hypersensitive intellectual performativityandthe practical wisdom needed for the purposes ofsocial engineering based on the actual active involvement of the people and sometimes asking them to propose the course of popular action. Thousands of Ogoni women and male citizens became deeply involved both as participants and organizers with Saro-Wiwa as the spirit behind, especially with the support of the outside world. Motivations therefore derived from down the ladder upwards. This upward flow of content accounted for the high number of grassroots women groups, organizations and association that grew in Ogoni between 1991 and 2006.

Apart from the superordinate Kingdom level structures, all the affiliate organisations had roots/officers in wards, villages, clans, districts and even in churches. Membership and participation were massive. The overall character centred on popular participation and inclusivity. Women from villages held positions in the Federation of Ogoni Women Organization (FOWA) and affiliate bodies became entrenched not only in the smallest village units but also in the mentality of the member-organizer, actor/participant. Women were not just mere participants but were handed the control; they were made by their leadership to own the units to which they belonged within MOSOP or related organizations. In fact, they spoke for and on behalf of themselves by themselves. They were able to relate to the Ogoni struggle with their voices heard and countedeven courted. The voice of their leaders became the group's voice without dissent. The intellectual mixed with the analphabetic and class distinction was overshadowed by mission and revolutionary engagement. Initiatives became self-propelling and internally-generated. This resulted in greater solidarity and the fostering of a deep fellow feeling because they saw themselves as people with a common destiny, facing the same enemy.

The success brought by the women's appropriation of their voice became euphoric and allowed some form ofplanningmyopia to creep in. The women lost their steam and fell into disarray shortly after the murder of Ken SaroWiwa because they concentrated so much on the moment and ignored the imperative to entrench the strategies for sustenance.For instance, no charismatic woman emerged to continue to articulate the voice that was so trenchant in the heyday of the revolution and so, the absence of such a rallying figure after the trauma of wasting operations in the land precipitated the disappearance of the women's visibility and voice. Consequently, after the judicial murder of Ken SaroWiwa and the post-revolution persecutions carried out by the Nigerian state, FOWA started floundering and withered into insignificance. It must be noted that the then President of FOWA was only able to speak on behalf of Ogoni women because the prevailing circumstances permitted it and the consent to speak on their behalf was mutually surrendered. In effect, though she may have had no clout of her own outside the force of strength conferred on her position by virtue of consensual support, she was the authentic voice of the women and this accounted for all the successes recorded at the time.

To claim to speak on behalf of someone today, there ought to be conventional proceduresto determine the means of obtaining the requisite mandate, the power of attorney to represent and function as representative voice.Various intervening factors may at times frustrate even the most superficial of contacts between the victims of discomfort and the genuine advocate. The mandate of the represented confers legitimacy on the voice that speaks for it. Through it one can claim without contradiction that he or she is authentically speaking on behalf of another. In politics, this is obtained through the process of choice expressed in the ballot. The represented also reserves the right to withdraw the consent given. Oftentimes, this is not the case with groups that claim to speak on behalf of women, especially rural women who sometimes may not even know that someone is claiming to represent their interest in the city. With many contemporary 
non-governmental organizations and advocacy groups, this authority to represent and speak on behalf of others is oftenseized and appropriated by persons who were not invited, not consulted and who have consequently, no mandate in the first place to do so. They do not have the consent of the individuals they claim to represent. It is often canvassed in some of these cases that the intervention is motivated by public interest. At times, this public interest can be dubious and self-serving. Women can change this scenario by encouraging rural women to organize their own representation at least within this era of civilian rule without democracy. It must be borne in mind that though there may be a general situation facing most women, perspectives on the degree of that problem may be relative to different individuals. These differences can still be aggregated and presented but the voice must be seen as authentic.

Worse still, it is observed that in many instances, the so-called advocate may not have even met the represented in any capacity whatsoever. We notice this in urban women's acting on behalf of rural farmers, widows, cottage entrepreneurs and the general peasantry. In other words, there is a high probability that the self-selected representative lacks fundamental understanding of the matter at stake. Any form of mediatory intervention in the identified distortion becomes, as one writer puts it, a distorted intervention. Most so-called civil society organizations today are in this category. These organizations especially the ones claiming to represent women have mushroomed over the entire social space.Can their representations be taken as reflecting the voice of oppressed or concerned women if the women they claim to be fighting for do not even know these their "advocates at large"? I am of the view that this is the kind of crisis that has given rise to the type of negative comments that the campaign by groups of women for the release of the abducted Chibok school girls has elicited. The babel of negative reactions and criticisms (though clearly misplaced) against the continuous rallying for the girls are parts of the issue of mandate and the question of authentic voice.

Though the negative comments and criticisms are definitely misplaced but they raise a fundamental question on the way urban women often claim to speak on behalf of rural women as part of the general mobilisation against marginality and peripherality. When social mobilizations of the magnitude of the campaign for the return of the abducted Chibok girls are carried out by urban women groups that fail to liaise with the local women concerned, it smacks of elitism and pedantry. I therefore advocate a system where synergy is created between the representative and the represented through the working out of the means of obtaining the requisite mandate or consent to speak on behalf of the subaltern or in the alternative, create the necessary conditions that enable the victim to speak for herself. When victims are given both space and voice, it enriches the democratic space and promotes self-expression which will make the direct resolution of felt needs easier and more enduring. This is because it will be easier to measure the degree of satisfaction or manner of discontent easily in the presence and/or involvement of the victim. There are a number of advantages derivable from not haranguing the local woman but encouraging her to take possession of her voice and raise it against oppression because her perspectives on what may constitute oppression to her can be acutely very private and personal. This is the strategy that replicates itself in the novels of the female writer, Buchi Emecheta.

In her famous article "Can the Subaltern Speak?" Gayatari Chakravorty Spivak analyses Deleuze's argument on the nature and character of "representation" which she sees as problematic. According to her:

Two senses of representation are being run together as "speaking for," as in politics, and representation as "representation" as in art or philosophy. Since theory is also only "action," the theoretician does not represent (speak for) the oppressed group. Indeed, the subject is not seen as a representative consciousness (one re-presenting reality adequately). These two senses of representation - within state formation and the law, on the one hand, and in subjectpredication, on the other hand - are related but irreducibly discontinuous...Because "the person who speaks and acts... is always a multiplicity," no "theorizing individual ... [or] party or ... union" can represent "those who act and struggle" (FD, 206). Are those who act and struggle mute, as opposed to those who act and speak (FD, 206)? (qtd in...)

The argument here is that in establishing class struggle as a community of deprived persons, there must be a representation of identity to which members can relate. This identity is defined and located in the experiential essence of the agentive-subject simultaneously with that of the actor-representative that speaks. A shift in this community spirit dislocates them as represented and representative. In other words, there must be a locus of identity as the conscientizing impetus both in difference and in sameness and the object of protest should be central in terms of consequence to both subject-participants and actor-representative. This is essentially important because according to Spivak, "Class consciousness remains with the feeling of community that belongs to ... links and ... organizations, not to that other feeling of community whose structural model is the family." (277). Evidently, a superficial system of vocality and advocacy which makes a "monolithic collectivity of "women" in the list of the oppressed (but) whose unfractured subjectivity allows them to speak for themselves against an equally monolithic "same system" cannot be helpful.

It is also my contention as earlier indicated that the very notion of an 'unfractured subjectivity' in which all women's experience assumes a unicity of character is faulty and thus misleading.For instance, in the campaign for the release of the abducted Chibok girls, individual families are facing their private dilemmas differently. These dilemmas are differing 
and deeply personal. The degree of the trauma experienced by different families is also different and this cannot be theorized using a generalized template. Some of the families may have had only one girl as female member and as such she could have been either mother's or father's pet. The level of distress in such families cannot be the same as the family in which there are more girls still in the family. A repudiation of the primacy of this difference is tantamount to silencing of difference in sameness or the entrenchment of self-denial as Mary Beard observes in her online article "The Public Voice of Women." In her words, "... if we want to understand - and do something about - the fact that women even when they are not silenced, still have to pay a very high price for being heard, we have to recognise that it is a bit more complicated and that there's a long back-story." In other words, there is a retinue of realities behind every voice and these realities condition action.

But then what is this voice and what are its dimensions? Can the voice in the city claiming to speak on behalf of rural women not be considered as the representations of bourgeois women who are far removed from the reality of the vast majority of the oppressed and voiceless woman? When a man actively canvasses for the rights of the woman, is he responding to Bell Hook's invitation that since "men are the primary agents maintaining and supporting sexism and sexist oppression, they can only be eradicated if men are compelled to assume responsibility for transforming their consciousness and the consciousness of society as a whole?" (Feminist Theory 2000)Can a man represent the experiential reality effectively without gendered bias? An unsigned Wikipedia review article claims that it is Hook's contention that:

A shift that will undoubtedly emerge as the struggle to end sexual oppression will be decreased obsession with sexuality ...sexuality will no longer have the importance attributed to it in a society that uses sexuality for the express purposes of maintaining gender inequality, male domination, consumerism, and the sexual frustration and unhappiness that deflect attention away from the need to make a social revolution.

Bell Hooks admits that men are part of the feminist movement and prefers to say that she advocates feminism for all because men also suffer as a result of sexism. When men speak on behalf of women, it is the principles of feminism rooted in humanism that are at work.Contemporary critics often feel that men cannot truly get to the farthest depths of a woman's experience and vice-versa. They further argue that stasis in social circumstances involving women is generated by men and they cannot objectively claim to be fighting the woman's cause. Beard reminds us that even from classical times, there were only two circumstances in which women were allowed to speak: as victims and as martyrs usually to preface their own death.However, contemporary reality attests to the effectiveness of male performativity in female consciousness- raising. But are all these adequate to conclude that the woman whose reality is transmitted through various forms of mediation has finally recovered her voice and she is now speaking? To an extent, the response can be affirmative or negative.

It is imperative that the rural woman must reclaim her voice in order to valorise micrological power over the macro logical domination and vocality of the subsuming urban voice which relays totalizing narratives in the name of all women without making visible impact in the lives of the rural woman. The urban voice, just like the patriarchal voice, can hardly represent the rural woman's interest and adequately project her vision. This is because the struggle between the urban male and urban female centres around the domination of space while the rural woman's trauma appears even more physiological than political and economic. Outside Nigeria, rural and slum-dwelling Brazilian women have organised themselves into various powerful movements in the favelas. This has raised the level of the power and influence of their voice in telling their own stories and shaping their future. Julia Lesage reports also in her article "Women's Rage" that Nicaraguan women who took active part in the revolution in their country had a more positive story to tell in terms of the new developments in theirlives in 1981 with the near elimination of wife and child abuse. Their participation ranked at about 50\% of the popular militias ensured that they took front positions in charting the course of change. Here, we are witnesses to the positive effect of inclusive participation in which individuals are involved directly. This participation makes the movement for change a grassroots mobilization in which people take responsibility for their action and inaction and this participation creates a further awareness in the subject to the potency of their own self-propelling initiative. This demonstrates the efficacy of libertarian feminism which sees people as self-owners who are protected from any form of coercive interferences but rather motivated by self-will and internally-generated initiatives.

Most often when rural women are organised for enlightenment, the needless hysteria and preoccupation with media coverage takes the shine off the foundation of the nagging problems the women face individually. The hypnosis over publicity becomes a central focus than empirical solutions to the problems identified. In the final analysis, there is more show than substance and some of the forms of advocacy are more attention-seeking than genuine efforts to mediate in favour of equity. For instance, recently the International Federation of Women Lawyers (FIDA) raised the alarm in a case of alleged detention of some women in a private hospital in the Diobu area of Port Harcourt because of their inability to settle their bills after delivery. The manner in which FIDA raised the alarm and the statement from the 
operators of the hospital showed a level of misinformation on the part of FIDA whose protest on radio gave the impression that the services rendered by the hospital were supposed to be free. The women in spite of the FIDA alarm agreed to pay their bills in instalments after it was discovered that one of them even had enough money to foot the bill but was determined not to pay leading to the false alarm.

Walter Brogan (2012) identifies authentic speaking as "one that resonates from the being of the one that is speaking". In other words, the one speaking must identify with the issue spoken about because it is part of experiential materiality. This is not to imply that advocacy only resonates when the issues are personal experiences. What is suggested is that in the kind of advocacy and mobilization in Nigeria on behalf of women in the pursuit of gender balance, visibility and vocality, there must be the involvement of the rural women themselves in such a way that their personal feelings and reactions to issues that affect their lives could be reproduced with obvious fidelity and immediacy. In the words of Loreen N. Olson (2004):

"Voice reflects the meaning that resides in an individual. Our voices are multivocal, reflecting the many selves within each of us (Ellis, 1997; Goodall, 200; Lincoln, 1997, Pinar, 1997). ...by exploring the concept of voice, via personal narratives or stories, we can understand how individuals as social and cultural speaking subjects form their selfidentities through interaction (Kerby, 1997; Gergen \& Gergen, 1997; Holstein\& Gubrium, 2000; Strine, 1997).

The issue raised here is the political dimensions of voice because in the utterance of a voice there is a baggage of background attitude, contexts and experiences that shape the tone, strength and authenticity of any voice whatsoever. This has implication for content and meaning. Thus, our voice reproduces our attitude to the reality at stake since a speaker's voice is a load of his temperament, prejudices and predilections. It is important therefore that the voice that represents the trauma of a group must not only reproduce the reality of that group, but must demonstrate empathic affinity with the subject of concern and must actively seek to not only speak on behalf of the subject but also to remove those pre-formed prejudices that may interfere and restructure the character of voice. In other words, speaking on behalf of a people requires a different set of conditions than speaking for self since experiences are private. This is one way a voice that speaks on behalf of a woman can be said to be legitimate and authentic because it resonates from the being and at one-ness with the being.

\section{References}

Addelson, Kathryn. (1983). Theman of professional wisdom. In Harding and Merrill Hintikka (eds.),Discovering reality(pp. 213315).Dordrecht, Holland: D. Reidel; Boston: Kluwer.

Beard, Mary. (2014). Thepublic voice of women.Retrieved from http://www.Irb.co.uk

Brogan, Walter. (2012). Thevoices that I am.Mosaic:A Journal for the Interdisciplinary Study of Literature.Retrieved from http://elibrary.bigchalk.com/elibweb/do

Code, Lorraine. (1991). What Can She Know?thaca, New York; Cornell University Press.

Fausto-Sterling, Anne. (2012). Retrieved from http://www.scribd.com/doc

Hooks, Bell.(1984). Feminist Theory: From Margin to Center. Cambridge, MA: South End Press.

Lesage, Julia.(1988).Women's rage. In Cary Nelson and Lawrence Grossberg (eds.),Marxism and theinterpretation of culture (pp. 419428). London: Macmillan Education Ltd.

Olson, Loreen N. (2004). The role of voice in the (re)construction of a battered woman's identity: An Autoethnography of one woman's experiences... Retrieved fromhttp://elibrary.bigchalk.com/elibweb

Spivak, Gayatri Chakravorty. (1988). Can the subaltern speak? In Cary Nelson and Lawrence Grossberg(eds.),Marxism and the interpretation of culture (pp. 271-313). London: Macmillan Education Ltd.Web. http://en.wikipedia.org/w/index.php? 